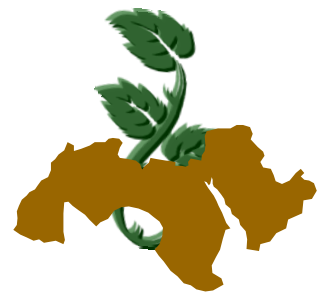

\title{
OPTIMIZATION OF A CULTURE MEDIUM FOR BIOMASS AND ठ-ENDOTOXIN PRODUCTION BY A RECOMBINANT ESCHERICHIA COLISTRAIN
}

\author{
Gamal, Rawia', F.; S.R. Al-Fateh ${ }^{2}$; Abeer M. Mohammed ${ }^{2}$ and M. El-Sawy' ${ }^{1}$ \\ 1- Dept. Microbiol., Fac. Agric., Ain Shams University, Shobra El-Khema, Cairo, Egypt \\ 2- Plant Protection Research Institute, Agric. Research Center, Dokki, Giza, Egypt
}

Keywords: Recombinant Escherichia coli, Biomass, $\delta$-endotoxin production, Medium optimization

\begin{abstract}
A recombinant strain of Escherichia coli harboring a plasmid containing the Bacillus thuringiensis $\delta$-endotoxin synthesis gene, was tested for its efficacy to synthesize $\delta$-endotoxin, in a complex medium containing sucrose and yeast extract. Also, the recombinant $E$. coli strain was tested for its efficacy against the $2^{\text {nd }}$ instars of Spodoptera littoralis. The recombinant strain of $E$. coli showed a good activity against the $2^{\text {nd }}$ instars of $S$. littoralis, the mortality was $70 \%$ after 7 days at room temperature. A high cell biomass $\left(8.8 \mathrm{gL}^{-1}\right)$ and $\delta$-endotoxin concentration $\left(6.8 \mathrm{mg} \mathrm{L}^{-1}\right)$, were obtained by the shake flask culture $(100 \mathrm{ml}$ medi$\mathrm{um} / 250 \mathrm{ml}$ flask, at $200 \mathrm{rpm}$ ), of the recombinant E. coli in modified MR medium containing sucrose $(20 \mathrm{~g} / \mathrm{L})$, as carbon source and yeast extract as nitrogen source, in the presence of $\mathrm{CaCO}_{3}$, $\mathrm{K}_{2} \mathrm{HPO}_{4}, \mathrm{MgSO}_{4}, \mathrm{FeSO}_{4}$ and $\mathrm{ZnSO}_{4}$ as mineral salts. The best $\mathrm{pH}$ values for cell biomass production and endotoxin production were 7.0 and 7.5, respectively. The corresponding figures for the best temperature were $37^{\circ} \mathrm{C}$ and $30^{\circ} \mathrm{C}$, respectively. The use of some byproducts such as blackstrap molasses, corn-steep liquor and cheese whey, as an alternative for carbon and nitrogen sources of medium, were found to enhance the cell growth but showed no effect on endotoxin production.
\end{abstract}

\section{INTRODUCTION}

The genetic manipulation of Cry genes of B.t. offers a promising mean for improving the efficacy of B.t.-based bioinsecticides products (Chak and Ellar, 1987 and Baum et al 1990). The Cry genes are localized on large plasmids, the isolation of these genes; their manipulation in vitro and their expression in different organisms are the most powerful and versatile research strategies in modern biology (Liu et al 2000 and Lee et al 2005).

Mohammed, (2003) and Gamal et al (2003) isolated from Egyptian soils, two strains of Bacillus thuringiensis, highly effective against the $2^{\text {nd }}$ instars of the cotton leafworm Spodoptera littoralis. They found that, CryI gene of these two strains, is responsible for the insecticidal proteins, of the parasporal crystalline inclusions. They also found that maximum spore formation by these two B.t. isolates, was attained when glucose and yeast extract were used in medium as carbon and nitrogen sources.

The present study aimed to investigate optimum nutritional and environmental requirements on cell biomass and $\delta$-endotoxin production, by recombinant $E$. coli strain, effective against the $2^{\text {nd }}$ instars of cotton leafworm Spodoptera littoralis

\section{MATERIALS AND METHODS}

\section{Recombinant $E$. coli}

Recombinant E.coli, which contains CryI gene, used in the present investigation, was kindly provided from Genetics Dept., Fac. of Agriculture, Cairo University.

The recombinant strain was constructed by cloning the CryIAc gene, (the gene encoding for the insecticidal cryIAc protein that is toxic to Spodoptera pests), from Bacillus thuringiensis into the broad host-range plasmid pUC18, as a vector, 
containing a constitutive ampicillin promoter that codes for ampicillin resistance, using pUC18 vector ligation reaction(Abdallah, 1990).

\section{Bioassay}

\section{Crystalline protein isolation}

Purification of insecticidal crystal protein (ICP) from recombinant $E$. coli was done according to Chak and Ellar, (1987) as follows: cultures were prepared and sonicated, then the disrupted cell suspension was centrifuged and the pellet, containing the toxin proteins, was resuspended in $5 \mathrm{ml}$ sterile distilled water. The inclusions were suspended on sucrose gradients, harvested, washed three times in distilled water and resuspended in distilled water. Samples were stored at $-20^{\circ} \mathrm{C}$.

\section{Insect bioassay with $\delta$ - endotoxin}

Cell extracts $(1 \mathrm{ml})$ containing approximately $425 \mu \mathrm{g}$ proteinious toxin, were brushed on each side of $4-5 \mathrm{~cm}$ diameter castor bean leaves discs. The discs were dried in air and then placed in a glass jar with 10 of $2^{\text {nd }}$ instars Spodoptera littoralis larvae. The number of dead larvae was recorded after 2 to 7 days incubation at room temperature (Chak and Ellar 1987).

\section{Statistical analysis of the bioassay data}

Numbers of living and dead insect larvae were counted in control (C) and toxin (T) treatments. As mortality percentage in control larvae ranged from 5-20\%, obtained data were corrected according to the Abbot's formula, 1925, then, $\mathrm{LC}_{50}$ and $\mathrm{LC}_{90}$ values were determined.

Data of LC- values at $5 \%$ confidence limits and slopes of regression lines were represented and interpreted using probit analysis statistical method of Litchfield and Willcoxon, (1949).

$$
\text { Corrected mortality \% }=\frac{T-C}{100-C} \times 100
$$

Where, $\mathrm{LC}_{50}=$ the lethal concentration that kills $50 \%$ of the tested larvae.

$\mathrm{LC}_{90}=$ the lethal concentration that kills $90 \%$ of the tested larvae.

\section{Standard curves}

Standard curves were constructed to correlate between optical density and cell dry weight, as well as between optical density and endotoxin produced by recombinant $E$. coli strain.

Yet, serial dilutions of recombinant E. coli strain were prepared in LB medium (Atlas, 1998). After $36 \mathrm{hr}$ incubation at $37^{\circ} \mathrm{C}$, cell dry weight and $\delta$ - endotoxin produced by recombinant $E$. coli strain were determined according to Liu et al (2000) and Chak \& Ellar, (1987). Also, optical density for growth was recorded spectrophotometrically at $600 \mathrm{~nm}$, according to (Liu et al 2000), and $\delta$ - endotoxin produced by recombinant $E$. coli strain was recorded spectrophotometrically at 280 nm (Chak and Ellar 1987).

Cell dry weight and $\delta$-endotoxin production were plotted on $\mathrm{X}$ axis, whereas optical density was plotted on $\mathrm{Y}$ axis. Cell dry weight of recombinant $E$. coli strain plotted against the optical density obtained by spectrophotometer at $600 \mathrm{~nm}$, were fed to Costat program for statistical analysis, which gave the following simple correlation (Fig. 1).

$$
Y=0.27+0.2 X \ldots \ldots \ldots \ldots(1)
$$

Where, $\mathrm{Y}$ is the absorbance at $(600 \mathrm{~nm})$. $\mathrm{X}$ is the cell dry weight $(\mathrm{g} / \mathrm{L})$,

Also, $\delta$ - endotoxin concentration, produced by recombinant $E$. coli strain, were fed to Costat program for statistical analysis, which gave the following simple correlation (Fig. 2),

$$
Y=0.19+0.26 X \ldots \ldots \ldots . . .(2)
$$

Where, $\mathrm{Y}$ is the absorbance at $(280 \mathrm{~nm})$.

$\mathrm{X}$ is the $\delta$ - endotoxin concentration $(\mathrm{mg} /$ $\mathrm{L})$.

Selection of suitable medium for $E$. coli growth and $\delta$ - endotoxin production

Three types of media being LB medium (Atlas, 1998), M9 medium (Trushin, 2003) and MR medium (Wang and Lee, 1997), were used in this study in order to select the most suitable medium for securing high production of cell dry weight and $\delta$ - endotoxin production.

\section{Effect of carbon and nitrogen sources}

Sixteen sources of carbon were used instead of the original carbon source in the selected MR medium. Also thirteen sources of nitrogen were used, for preparing the medium. It was put in consideration that the percentage of carbon and nitrogen in 


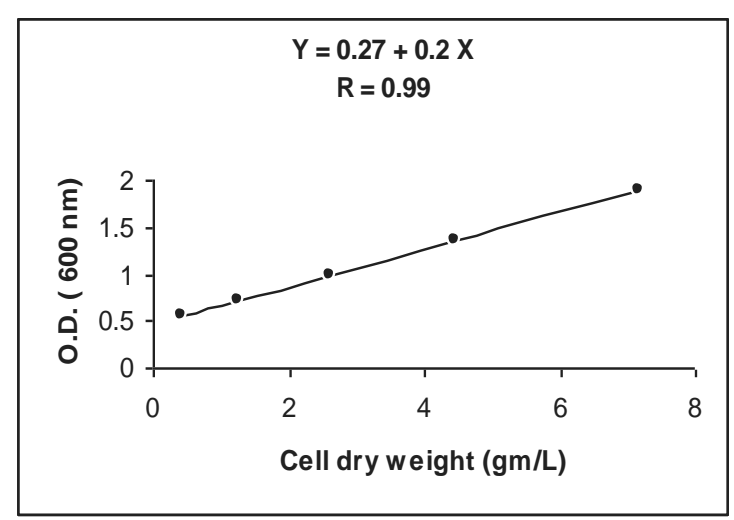

Fig. 1. Standard curve for cell dry weight determination, for recombinant $E$. coli strain

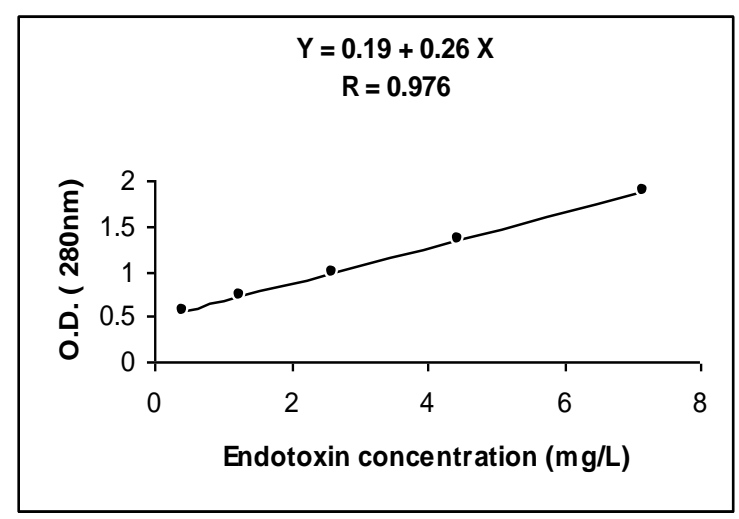

Fig. 2. Standard curve for $\delta$-endotoxin determination produced by recombinant $E$. coli

the alternative sources, were the same with those in the original sources in the selected medium, in order to eliminate errors which may result from the variation of the added sources. The sterile broth medium was inoculated with $1 \mathrm{ml}$ of standard inoculum. Then the inoculated flasks were incubated on a rotary shaker $200 \mathrm{rpm}$ at $37^{\circ} \mathrm{C}$ for 36 hours. The cell dry weight and $\delta$-endotoxin concentration were determined by spectrophotometer (Liu et al 2000).

\section{Effect of sugar concentration}

Under the best carbon and nitrogen sources, the medium was used with different sugar concentrations (ranging from $10 \mathrm{gm}$ of the carbon source per liter up to $25 \mathrm{gm}$ ), to study their effect on cell biomass and toxin production by the tested strain.

\section{Effect of inorganic salts}

Five treatments were performed to study the effect of absence of each of $\mathrm{KH}_{2} \mathrm{PO}_{4}, \mathrm{MgSO}_{4}$, $\mathrm{CaCO}_{3}, \mathrm{ZnSO}_{4}$ and $\mathrm{FeSO}_{4}$ on cell yield and endotoxin production using the medium, with best tested carbon and nitrogen sources, then the results were compared.

\section{Effect of initial pH}

The medium, with best tested carbon and nitrogen sources, was used to study the effect of $\mathrm{pH}$ on cell yield and endotoxin production of the recombinant $E$. coli. The media were prepared and adjusted to several different pHs (5.5 up to 9.5) by using standard solutions of $\mathrm{HCl}$ and $\mathrm{NaOH}$. The media were sterilized and inoculated with $1 \mathrm{ml}$ of standard inoculum of cell suspension. The cultures were incubated at $37^{\circ} \mathrm{C}$ for 36 hours. The cell dry weight was determined spectrophotometrically.

\section{Effect of incubation temperature}

The modified MR medium was prepared and adjusted to the optimum $\mathrm{pH}$. The sterile medium was inoculated with $1 \mathrm{ml}$ standard cell suspension ( $0.22 \mathrm{gm}$ dry cells/L) and then incubated at different temperatures (ranging from $20^{\circ} \mathrm{C}$ to $40^{\circ} \mathrm{C}$ ), then cell dry weight and endotoxin were determined spectrophotometrically.

\section{Effect of aeration}

In order to test the effect of aeration on bacterial growth, two procedures were performed by:

1- Using shaking cultures in flasks, containing modified medium, at different speeds ranging from 160-250 rpm, then the cell dry weight and endotoxin concentration at the end of incubation period were determined and compared.

2- Using different volumes of selected medium, being $25,50,75,100$ and $125 \mathrm{ml}$ culture medium in the $250 \mathrm{ml}$ shaking flasks, for growing the recombinant $E$. coli strain, with consideration that, the shaking speeds and all the other factors affecting the growth were constant.

\section{Effect of some by-products}

Some local by-product materials as alternative carbon and nitrogen sources in MR medium, were used for growth and $\delta$-endotoxin production. These materials were obtained from different sources as follow: 


\begin{tabular}{cc}
\hline by-product & Source \\
\hline $\begin{array}{c}\text { Black-strap cane } \\
\text { molasses }\end{array}$ & $\begin{array}{c}\text { Sugar refinery factory- } \\
\text { ElHawamdia }\end{array}$ \\
\hline Corn-steep liquor & $\begin{array}{c}\text { Glucose and Starch Co. } \\
\text { Kozzica }\end{array}$ \\
\hline Cheese whey & $\begin{array}{c}\text { Egypt dairy products Co. } \\
\text { ElAmeria }\end{array}$ \\
\hline
\end{tabular}

Molasses ( $58 \%$ carbon), was diluted by addition of water in ratio of $1: 1$, hydrolyzed at $100^{\circ} \mathrm{C}$ and $\mathrm{pH} 5.0$ for $60 \mathrm{~min}$, then, $\mathrm{pH}$ was adjusted to 7.5 with $\mathrm{Ca}(\mathrm{OH})_{2}$ after cooling to about $60^{\circ} \mathrm{C}$, and kept overnight to remove the precipitated undesirable metal salts. The supernatant was sterilized for $30 \mathrm{~min}$ at $112^{\circ} \mathrm{C}$ and added to the medium (14 ml $/ \mathrm{L})$ at room temperature.

Cheese whey is the major by-product of cheese manufacturing, representing about $80 \%$ of the volume of milk transformed. It contains approximately $4.5 \%(\mathrm{w} / \mathrm{v})$ lactose, which in turn, contains $40 \%$ carbon. It was added to the medium in about $400 \mathrm{ml} / \mathrm{L}$.Corn steep liquor contains about $3.5-4 \%(\mathrm{w} / \mathrm{v})$ nitrogen. It was added to the medium in $16 \mathrm{ml} / \mathrm{L}$.

In preparing the medium, it was put in consideration that the percentage of carbon and nitrogen in the alternative by-product sources, were the same with those in the original sources in MR medium, in order to eliminate errors which may result from the variation of the added sources.

\section{Growth parameters}

The modified MR medium was dispensed into $250 \mathrm{ml}$ cotton plugged Erlenmyer flasks, then inoculated with standard inoculum, and incubated for 36 hours on a rotatary shaker. Samples $(10 \mathrm{ml})$ were taken periodically every 3 hours intervals and the cell dry weight and endotoxin concentration were determined spectrophotometrically as mentioned before. The relationship between cell dry weight and time was plotted, specific growth rate and doubling time were calculated from the exponential phase, according to Painter \& Marr (1963), using the following equation:-

$$
\mu=\left(\ln X_{t}-\ln X_{o}\right) /\left(t_{t}-t_{o}\right)=\ln 2 / t_{d}
$$

Where,

$$
\begin{aligned}
\mu & =\text { Specific growth rate }\left(\mathrm{h}^{-1}\right) \\
\mathrm{X}_{\mathrm{t}} & =\text { Amount of cells at } \mathrm{t} \text { time }(\mathrm{g} / \text { liter }) \\
\mathrm{X}_{\mathrm{O}} & =\text { Amount of cells at zero time }(\mathrm{g} / \text { liter })
\end{aligned}
$$

$t_{t}=$ time in hours at the end of log phase.

$\mathrm{t}_{0}=$ time in hours at the beginning of log phase.

$\mathrm{t}_{\mathrm{d}}=$ Doubling time $(\mathrm{h})$.

- The $\delta$-endotoxin content $(\%)$ was calculated according to Lee \& Chol (1998) by the following equation:-

\section{gm toxin $\times 100 /$ gm biomass dry weight}

\section{RESULTS AND DISCUSSION}

\section{Toxicity of recombinant $E$. coli against the $2^{\text {nd }}$ instars of Spodoptera littoralis}

Data in Table (1) and Fig. (3) clearly show that, the recombinant strain of $E$. coli revealed a good activity against the $2^{\text {nd }}$ instars of Spodoptera littoralis. The recorded mortality was $70 \%$ after 7 days at room temperature. These results are in line with those obtained by Baum et al (1990) who cloned cryIAc from B.t. subsp. aizawai in E. coli. They found that, the recombinant strain exhibited good insecticidal activity against Spodoptera littoralis.

\section{Selection of suitable medium for production}

Escherichia coli is a facultatively anaerobic bacterium, having both a respiratory and a fermentative type of metabolism. Also it is a chemoorganotrophic bacterium that depends on organic compounds as source of carbon and energy, Sneath et al (1986).

Data presented in Table (2) show the optical density of growth and specific growth rate and $\delta$ endotoxin concentration of recombinant $E$.coli during incubation period in the three tested media (LB, MR and M9 media). Results clearly show that, there was a slight difference in cell biomass between LB and MR media. While there were significant differences in $\delta$-endotoxin concentration using the three types of media. The cell dry weight and the specific growth rate were $8.3 \mathrm{~g} / \mathrm{L}$ and $0.65 \mathrm{~h}^{-1}$ using LB medium. The corresponding figures for M9 medium were $5.2 \mathrm{gm} / \mathrm{L}$ and 0.52 $\mathrm{h}^{-1}$. MR medium exhibited the same trend of LB medium. While, the endotoxin concentration using the three media was $5.1,5.3$ and $2.8 \mathrm{mg} / \mathrm{L}$ in LB, MR and M9 media, respectively.

From the aforementioned results, it could be stated that MR medium was preferred for both cell biomass and $\delta$-endotoxin production. So, this medium was chosen for further investigations. 
Table 1. Efficacy of recombinant E. coli against the $2^{\text {nd }}$ instar larvae of Spodoptera littoralis

\begin{tabular}{|c|c|c|c|c|c|c|}
\hline \multirow{2}{*}{ Bacterial strain } & \multicolumn{6}{|c|}{$\begin{array}{l}\text { *Cumulative corrected mortality } \% \text { after indicated days } \\
\text { post treatment }\end{array}$} \\
\hline & 2 & 3 & 4 & 5 & 6 & 7 \\
\hline Recombinant $E$. coli & 0 & 10 & 20 & 40 & 40 & 70 \\
\hline B.t. kurstaki** & 0 & 20 & 30 & 40 & 50 & 80 \\
\hline Control (dist. water) & 0 & 0 & 0 & 0 & 0 & 0 \\
\hline
\end{tabular}

Standard inoculum suspension contains $0.22 \mathrm{gm}$ dried cells $/ \mathrm{L}$.

* Cumulative corrected mortality was calculated according to Abbott's formula, 1925.

** Obtained from Cairo MIRCEN - Fac. of Agric. Ain Shams Univ., Cairo.

Table 2. Cell dry weight, Specific growth rate $(\mu)$ and $\delta$ - endotoxin concentration of recombinant $E$. coli strain grown on different media using shake flasks as a batch culture, after 36 hours of incubation.

\begin{tabular}{|ccccccc|}
\hline & \multicolumn{3}{c}{ Cell dry weight $(\mathrm{gm} / \mathrm{L})$} & \multicolumn{3}{c|}{$\delta$ - endotoxin } \\
\cline { 2 - 7 } Media type & O.D. & $\mathrm{gm} / \mathrm{L}$ & $\mu\left(\mathrm{h}^{-1}\right)$ & O.D. & $\mathrm{mg} / \mathrm{L}$ & Content $(\%)$ \\
\hline LB $^{(1)}$ & 1.9 & $8.32^{\mathrm{a}}$ & 0.65 & 1.5 & $5.1^{\mathrm{b}}$ & 0.060 \\
$\mathrm{MR}^{(2)}$ & 1.9 & $8.31^{\mathrm{a}}$ & 0.65 & 1.5 & $5.3^{\mathrm{a}}$ & 0.063 \\
$\mathrm{M9}^{(3)}$ & 1.3 & $5.20^{\mathrm{b}}$ & 0.52 & 0.92 & $2.8^{\mathrm{c}}$ & 0.054 \\
\hline
\end{tabular}

- Standard inoculum was 0.22 gm dried cells $/ \mathrm{L}$.

- Values in the column having the same letter are not significantly differed, $(P=0.05 \%)$.

- Data were analyzed by Duncan's multiple range test (1951).

(1) L.B. (Luria broth) medium (Atlas, 1998), consists of:Yeast extract, $5.00 \mathrm{~g}$; Tryptone, $10.0 \mathrm{~g}$; NaCl, $10.0 \mathrm{~g}$; Dist. water, $1000 \mathrm{ml} ; \mathrm{pH}, 7.00$.

(2) MR medium (Wang and Lee, 1997), consists of: $\left(\mathrm{NH}_{4}\right)_{2} \mathrm{HPO}_{4}, 3.0 \mathrm{~g} ; \mathrm{KH}_{2} \mathrm{PO}_{4}, 2.2 \mathrm{~g} ; \mathrm{MgSO}_{4} .7 \mathrm{H}_{2} \mathrm{O}$,

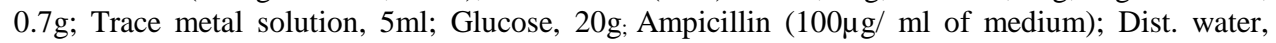
$1000 \mathrm{ml} ; \mathrm{pH}, 7.0$.

(3) M9 medium (Trushin, 2003), consists of: $\mathrm{Na}_{2} \mathrm{HPO}_{4}, 6 \mathrm{~g} ; \mathrm{KH}_{2} \mathrm{PO}_{4}, 3 \mathrm{~g} ; \mathrm{NaCl}, 0.5 \mathrm{~g} ; \mathrm{NH}_{4} \mathrm{Cl}, 1 \mathrm{~g}$; Glucose, $10 \mathrm{~g}$; Dist. water, $1000 \mathrm{ml}$; pH,7.5. 


\section{Effect of carbon sources}

It is quite natural that different carbon compounds vary in their nature and number of carbon atoms. Such various carbon compounds could be used as an energy and carbon sources for bacterial growth. Therefore, it was found of interest to study the influence of the nature of carbon sources on the cell dry weight and $\delta$ - endotoxin concentration.

The percentage of carbon present in the MR medium was replaced by equivalent amount of each of the tested carbon source, i.e., organic sources namely, sucrose, glucose, fructose, lactose, maltose, mannose, galactose, arabinose, $x y-$ lose, ribose, glycerol ,mannitol and starch, as well as inorganic sources namely, potassium carbonate and sodium carbonate.

Tabulated data presented in Table (3), clearly show that the ability of the E. coli strain to give high yield of cells was markedly affected by the source of carbon in the media $[P=0.05 \%]$. Using MR medium, the statistical analysis proved that the addition of sucrose gave maximum cell dry weight of the $E$. coli strain. Results revealed that the cell dry weight was $8.5 \mathrm{gm} / \mathrm{L}$. It is noteworthy to state that the minimal dry weight, was detected when mannitol was used as a main source of carbon in MR medium. The same effect was also obtained by addition of inorganic carbon sources.

With respect to growth parameters of different carbon sources, results also clearly show that, the growth parameters gave the same trend, where the highest figures of specific growth rate $(\mu)$, were recorded by using sucrose being $0.67 \mathrm{~h}^{-1}$ then, by using glucose $\left(0.65 \mathrm{~h}^{-1}\right)$. Similar values of specific growth rates were recorded by using fructose. The lowest values of specific growth rates were observed when using xylose, mannitol, K-citrate and inorganic carbon sources.

In conclusion, it could be stated that, when sucrose was supplemented instead of glucose in the original medium, an obvious improvement of cell yield of the recombinant $E$. coli strain, was achieved, as compared to other tested carbon sources.

Results of endotoxin production indicated that, the highest concentration $(6.4 \mathrm{mg} / \mathrm{L})$ and content $(0.075 \%)$ was observed on MR medium containing sucrose $(20 \mathrm{~g} / \mathrm{L})$ as a sole carbon source, after $36 \mathrm{hrs}$ incubation period, followed by glucose, fructose, galactose, mannose and glycerol in descending order. The corresponding figures for endotoxin content $(\%)$ were $0.075,0.061,0.060$, $0.060,0.064$ and 0.07 respectively.
Therefore, sucrose was applied in the following studies. The MR medium, which contains sucrose $(20 \mathrm{~g} / \mathrm{L})$ instead of glucose, will be designated as MR1.

Comparing the previous data with those obtained by Liu et al (1998), it was found that, fructose offers a reasonable alternative for glucose in $E$. coli fermentation, since its uptake and utilization are more tightly regulated and higher biomass yields were attained. While, (Shuishan et al 1999 \& Liu et al 2000 and Marounek et al 2003) preferred glucose as carbon source for growth of recombinant strains of $E$. coli to achieve high cell density in comparison with different carbon sources. Other authors used by-products as carbon sources such beet molasses (Liu et al 1998), highly concentrated whey solution (Ahn et al 2000), and deproteinized milk whey powder (Nikel $\boldsymbol{e t}$ al 2005) in a large scale industrial production because of the low cost of these by-products.

\section{Effect of sucrose concentration}

Five sucrose concentrations, being 10, 12, 16, 20 and $25 \mathrm{gm} / \mathrm{L}$ were employed to investigate their effect on $\delta$ - endotoxin synthesis in recombinant $E$. coli cells. The experimental results for the final cell densities and $\delta$ - endotoxin concentrations are shown in Table (4). In all cases, higher cell concentration was obtained with higher concentration of sucrose, till reaching maximum at $20 \mathrm{gm}$ per liter.

The tabulated data of cell dry weight, $\delta$ endotoxin concentration and growth parameters clearly show that, the highest cell dry weight and specific growth rate $(\mu)$ were the highest at 20 $\mathrm{gm} / \mathrm{L}$ sucrose. The cell dry weight and the specific growth rate were $8.4 \mathrm{gm} / \mathrm{L}$ and $0.67 \mathrm{~h}^{-1}$ after 36 $\mathrm{hr}$ incubation, respectively. Also, endotoxin concentration was higher at the same concentration of sucrose, representing $6.3 \mathrm{mg} / \mathrm{L}$ with $0.076 \%$ content.

\section{Effect of nitrogen sources}

This experiment aimed to study the effect of different nitrogen sources on enhancing the growth of the recombinant $E$. coli strain and $\delta$ endotoxin production in MR1 medium. Thirteen nitrogen sources were tested i.e. ten sources of organic nitrogen including amino acids and three inorganic sources. Each source was added instead of ammonium phosphate in amount calculated to give the same concentration of nitrogen in order to 
Table 3. Growth parameters of recombinant E. coli as influenced by different carbon sources using shake flasks, at $37^{\circ} \mathrm{C}$, after $36 \mathrm{~h}$ of incubation

\begin{tabular}{|lcccc|}
\hline \multirow{2}{*}{ Carbon source } & \multicolumn{2}{c}{ Cell dry weight $(\mathrm{gm} / \mathrm{L})$} & \multicolumn{2}{c|}{$\delta$-endotoxin } \\
\cline { 2 - 5 } & $\mathrm{gm} / \mathrm{L}$ & $\mu\left(\mathrm{h}^{-1}\right)$ & $\mathrm{gm} / \mathrm{L}$ & Content $(\%)$ \\
\hline Sucrose & $8.5^{\mathrm{a}}$ & 0.67 & $6.4^{\mathrm{a}}$ & 0.075 \\
Glucose & $8.3^{\mathrm{b}}$ & 0.65 & $5.1^{\mathrm{b}}$ & 0.061 \\
Fructose & $8.2^{\mathrm{c}}$ & 0.64 & $4.9^{\mathrm{c}}$ & 0.060 \\
Galactose & $6.9^{\mathrm{d}}$ & 0.54 & $4.1^{\mathrm{f}}$ & 0.060 \\
Mannose & $6.7^{\mathrm{e}}$ & 0.58 & $4.3^{\mathrm{e}}$ & 0.064 \\
Lactose & $5.9^{\mathrm{j}}$ & 0.59 & $4.0^{\mathrm{g}}$ & 0.067 \\
Maltose & $6.1^{\mathrm{h}}$ & 0.61 & $4.0^{\mathrm{g}}$ & 0.065 \\
Mannitol & $4.1^{\mathrm{h}}$ & 0.44 & $2.6^{1}$ & 0.063 \\
Glycerol & $6.4^{\mathrm{g}}$ & 0.60 & $4.7^{\mathrm{d}}$ & 0.070 \\
Arabinose & $6.0^{\mathrm{i}}$ & 0.46 & $3.4^{\mathrm{k}}$ & 0.057 \\
Xylose & $5.6^{\mathrm{k}}$ & 0.54 & $4.1^{\mathrm{f}}$ & 0.066 \\
Ribose & $6.0^{\mathrm{i}}$ & 0.55 & $4.1^{\mathrm{f}}$ & 0.066 \\
Starch & $6.5^{\mathrm{f}}$ & 0.50 & $3.9^{\mathrm{h}}$ & 0.060 \\
K-citrate & $5.5^{1}$ & 0.50 & $3.9^{\mathrm{h}}$ & 0.065 \\
Na-carbonate & $5.4^{\mathrm{m}}$ & 0.53 & $3.5^{\mathrm{j}}$ & 0.064 \\
K-carbonate & $5.5^{\mathrm{l}}$ & 0.50 & $3.6^{\mathrm{i}}$ & 0.065 \\
\hline LSD & 0.06 & & 0.10 & \\
\hline
\end{tabular}

- Standard inoculum was $0.22 \mathrm{gm}$ dried cells /L.

- Values in the column having the same letter are not significantly differed.

- Data were analyzed by Duncan's multiple range test (1951).

Table 4. Growth parameters of recombinant E. coli as influenced by different sugar concentration using shaking flasks, at $37^{\circ} \mathrm{C}$, after $36 \mathrm{~h}$ of incubation

\begin{tabular}{|ccccc|}
\hline \multirow{2}{*}{$\begin{array}{c}\text { Sucrose concentration } \\
(\mathrm{g} / \mathrm{L})\end{array}$} & \multicolumn{2}{c}{ Cell dry weight } & \multicolumn{2}{c|}{$\delta$ - endotoxin } \\
\cline { 2 - 5 } & $(\mathrm{gm} / \mathrm{L})$ & $\mu\left(\mathrm{h}^{-1}\right)$ & $\mathrm{mg} / \mathrm{L}$ & Content $\%$ \\
\hline 10 & $7.9^{\mathrm{d}}$ & 0.6 & $4.7^{\mathrm{d}}$ & 0.059 \\
12 & $8.0^{\mathrm{c}}$ & 0.63 & $4.9^{\mathrm{c}}$ & 0.060 \\
16 & $8.3^{\mathrm{b}}$ & 0.66 & $5.3^{\mathrm{b}}$ & 0.063 \\
20 & $8.4^{\mathrm{a}}$ & 0.67 & $6.3^{\mathrm{a}}$ & 0.076 \\
25 & $7.0^{\mathrm{e}}$ & 0.55 & $3.7^{\mathrm{e}}$ & 0.050 \\
\hline LSD & 0.04 & & 0.30 & \\
\hline
\end{tabular}

- Standard inoculum was 0.22 gm dried cells /L.

- Values in the column having the same letter are not significantly differed.

- Data were analyzed by Duncan's multiple range test (1951). 
eliminate the error which may occur as a result of differences in nitrogen concentration of each source. Table (5) shows the cell dry weight, $\delta$ endotoxin concentration and growth parameters.

The highest figures of cell dry weight were detected when yeast extract was used instead of ammonium phosphate in MR1 medium for the tested strain $(8.8 \mathrm{gm} / \mathrm{L})$, as proved statistically. Data also show that powdered milk and amino acids had a drastic effect on the cell dry weight, since they gave $68 \& 67 \%$ of cell dry weight comparing to yeast extract as a source of nitrogen in MR medium, respectively.

Concerning the other tested nitrogen sources, data revealed that tryptone gave $98 \%$ of the cell dry weight, obtained by using yeast extract in MR1 medium, and peptone gave $8.5 \mathrm{gm} / \mathrm{L}$ representing $97 \%$ of cell dry weight obtained with yeast extract as nitrogen source.

Inorganic nitrogen sources showed a drastic effect on cell dry weight, since the $\mathrm{NaNO}_{3}$ and $\left(\mathrm{NH}_{4}\right)_{2} \mathrm{SO}_{4}$ gave $91 \%$ and $93 \%$ of cell dry weight, respectively comparing to yeast extract as a source of nitrogen in MR1 medium. With respect to growth parameters of different nitrogen sources, results also clearly show that, the growth parameters gave the same trend, where the highest figures of specific growth rate were recorded when yeast extract was used as nitrogen source in MR1 medium $\left(0.69 \mathrm{~h}^{-1}\right)$, followed by tryptone $\left(0.67 \mathrm{~h}^{-1}\right)$, peptone $\left(0.66 \mathrm{~h}^{-1}\right)$, ammonium phosphate $\left(0.67 \mathrm{~h}^{-1}\right)$, ammonium sulfate $\left(0.65 \mathrm{~h}^{-1}\right)$ then sodium nitrate $\left(0.63 \mathrm{~h}^{-1}\right)$. While all other nitrogen sources gave lower values of specific growth rate.

Results of endotoxin production indicated that, the highest concentration $(6.7 \mathrm{mg} / \mathrm{L})$ and content $(0.077 \%)$ were observed on MR1 medium containing yeast extract as a sole nitrogen source, after $36 \mathrm{hrs}$ incubation period. It is noteworthy to mention that, the use of combinations of amino acids as nitrogen source did not enhance cell growth as compared with yeast extract or ammonium phosphate, while it could enhance endotoxin production. The content (\%) was $0.07,0.07$ and $0.067 \%$ when combinations of (serine + alanine), (alanine + glysine) and (glysine + serine) were used as nitrogen sources, respectively. Therefore, yeast extract was applied in the following studies. The medium, which contains yeast extract instead of ammonium phosphate, will be designated as MR2.

These results are in line with those obtained by, Wang \& Lee, (1997) who used a complex medium containing yeast extract and tryptone for production of $\mathrm{P} \beta \mathrm{HB}$ by recombinant $E$. coli. A high $\mathrm{P} \beta \mathrm{HB}$ concentration with a high productivity could be obtained.

While, Ling et al (2001) added selected amino acids to improve production of recombinant proteins by recombinant $E$. coli. They found that glycine increased the maximum specific growth rate from 0.67 to $0.78 \mathrm{~h}^{-1}$.

\section{Effect of some by-product materials}

Some available by-products such as blackstrap molasses, cheese whey and corn-steep liquor, were used for biomass and endotoxin production by recombinant $E$. coli, using shake flasks as a batch culture, using MR medium. Data presented in Table (6) show that the production of biomass was high when molasses was used as carbon source instead of glucose, while the production of endotoxin was very low with all investigated byproducts, as compared with that produced on MR medium. Many authors, such (Ahn et al 2000) and Nikel et al 2005) preferred to use by-products for production of recombinant $E$. coli in the large scale production, since the by-products are considered to be easy obtainable and cheap nutritional sources.

Beet molasses successfully replaced glucose as sole carbon source to produce poly- $\beta$ hydroxybutyrate by a recombinant $E$. coli strain (Liu et al 1998). The final cell dry weight, $\mathrm{P} \beta \mathrm{HB}$ content and $\mathrm{P} \beta \mathrm{HB}$ productivity were $39.5 \mathrm{~g} / \mathrm{L}$, $80 \%(\mathrm{w} / \mathrm{w})$ and $1 \mathrm{~g} / \mathrm{L} / \mathrm{h}$, respectively, in a $5 \mathrm{~L}$ stirred tank fermenter after $31.5 \mathrm{~h}$ fed-batch fermentation with constant $\mathrm{pH}$ and dissolved $\mathrm{O}_{2}$.

\section{Effect of inorganic salts}

Although the modification of the medium was made in the original MR medium, it was found of interest to study the effect of presence or absence of every inorganic salt, on the growth and $\delta$ endotoxin production of the tested strain. Therefore, five treatments were performed to study the effect of salt absence of each of $\mathrm{KH}_{2} \mathrm{PO}_{4}, \mathrm{CaCO}_{3}$, $\mathrm{MgSO} 4, \mathrm{ZnSO} 4$ or FeSO4, on cell dry weight and endotoxin production. In any treatment, only one salt was lacking. These trials were compared with complete MR2 medium (control). Cell dry weight and endotoxin concentration were determined after incubation for 36 hours at $37^{\circ} \mathrm{C}$ for each treatment.

Data presented in Table (7) clearly show that in all treatments lacking any salt, the values of cell dry weight and endotoxin concentration were significantly decreased than that of the control 
Table 5. Growth parameters of recombinant E. coli as influenced by different nitrogen sources using shake flasks, at $37^{\circ} \mathrm{C}$, after $36 \mathrm{~h}$ of incubation

\begin{tabular}{|lcccc|}
\hline Nitrogen source & \multicolumn{2}{c}{ Cell dry weight } & \multicolumn{2}{c|}{$\delta$ - endotoxin } \\
\cline { 2 - 5 } & $(\mathrm{gm} / \mathrm{L})$ & $\mu\left(\mathrm{h}^{-1}\right)$ & $(\mathrm{mg} / \mathrm{L})$ & Content $\%$ \\
\hline Yeast extract & $8.8^{\mathrm{a}}$ & 0.69 & $6.7^{\mathrm{a}}$ & 0.077 \\
Tryptone & $8.6^{\mathrm{b}}$ & 0.67 & $6.0^{\mathrm{b}}$ & 0.068 \\
Peptone & $8.5^{\mathrm{c}}$ & 0.66 & $6.0^{\mathrm{b}}$ & 0.068 \\
Gelatin & $7.6^{\mathrm{g}}$ & 0.60 & $4.6^{\mathrm{f}}$ & 0.060 \\
Powdered milk & $6.0^{\mathrm{j}}$ & 0.58 & $3.4^{\mathrm{k}}$ & 0.056 \\
Urea & $6.8^{\mathrm{h}}$ & 0.64 & $4.3^{\mathrm{g}}$ & 0.063 \\
Sodium glutamate & $6.4^{\mathrm{i}}$ & 0.62 & $4.6^{\mathrm{f}}$ & 0.070 \\
Serine + Alanine & $5.9^{\mathrm{j}}$ & 0.57 & $4.2^{\mathrm{h}}$ & 0.070 \\
Alanine + Glycine & $5.8^{\mathrm{l}}$ & 0.56 & $4.1^{\mathrm{i}}$ & 0.070 \\
Glycine + Serine & $5.9^{\mathrm{k}}$ & 0.55 & $4.0^{\mathrm{j}}$ & 0.067 \\
$\mathrm{NaNO}_{3}$ & $8.0^{\mathrm{f}}$ & 0.63 & $4.9^{\mathrm{d}}$ & 0.060 \\
NH $\left._{4}\right)_{2} \mathrm{HPO}_{4}$ (control) & $8.4^{\mathrm{d}}$ & 0.67 & $5.1^{\mathrm{c}}$ & 0.060 \\
$\left(\mathrm{NH}_{4}\right)_{2} \mathrm{SO}_{4}$ & $8.2^{\mathrm{e}}$ & 0.65 & $4.8^{\mathrm{e}}$ & 0.059 \\
\hline $\mathrm{LSD}^{\mathrm{y} S}$ & 0.05 & & 1.1 & \\
\hline
\end{tabular}

- Standard inoculum was 0.22 gm dried cells /L.

- Values in the column having the same letter are not significantly differed.

- Data were analyzed by Duncan's multiple range test (1951).

Table 6. Effect of some industrial by-products on cell dry weight and $\delta$-endotoxin production by recombinant $E$. coli on MR medium, after $36 \mathrm{~h}$ at $37^{\circ} \mathrm{C}$ using shake flasks

\begin{tabular}{|lcccccc|}
\hline \multirow{2}{*}{\multicolumn{1}{c}{ By-product }} & \multicolumn{3}{c}{ Cell dry weight $(\mathrm{gm} / \mathrm{L})$} & \multicolumn{3}{c|}{$\delta$ - endotoxin } \\
\cline { 2 - 7 } & O.D. & $\mathrm{gm} / \mathrm{L}$ & $\mu\left(\mathrm{h}^{-1}\right)$ & O.D. & $\mathrm{mg} / \mathrm{L}$ & Content $(\%)$ \\
\hline Black-strap molasses & 2.0 & $9.3^{\mathrm{a}}$ & 0.7 & 1.28 & $4.2^{\mathrm{c}}$ & 0.045 \\
Cheese whey & 1.85 & $7.9^{\mathrm{b}}$ & 0.64 & 1.46 & $4.9^{\mathrm{a}}$ & 0.062 \\
Corn-steep liquor & 1.67 & $7.0^{\mathrm{c}}$ & 0.55 & 1.33 & $4.4^{\mathrm{b}}$ & 0.063 \\
\hline
\end{tabular}

- Standard inoculum was 0.22 gm dried cells /L.

- Values in the column having the same letter are not significantly differed, $(P=0.05 \%)$

- Data were analyzed by Duncan's multiple range test (1951).

Table 7. Effect of inorganic salts on cell dry weight and $\delta$-endotoxin production of recombinant $E$. coli on MR2 medium, after $36 \mathrm{~h}$ at $37^{\circ} \mathrm{C}$ using shake flasks.

\begin{tabular}{|lcccccc|}
\hline Media used & \multicolumn{3}{c}{ Cell dry weight } & \multicolumn{3}{c|}{$\delta$-endotoxin concentration } \\
\cline { 2 - 7 } & O.D. & gm / L & $\%$ & O.D. & gm / L & Content \% \\
\hline Medium - $\mathrm{KH}_{2} \mathrm{PO}_{4}$ & 1.91 & $8.2^{\mathrm{d}}$ & 93 & 1.75 & $6.0^{\mathrm{d}}$ & 0.073 \\
Medium - $\mathrm{MgSO}_{4}$ & 1.97 & $8.6^{\mathrm{c}}$ & 98 & 1.85 & $6.4^{\mathrm{c}}$ & 0.074 \\
Medium - $\mathrm{CaCO}_{3}$ & 1.87 & $8.0^{\mathrm{c}}$ & 91 & 1.72 & $5.9^{\mathrm{e}}$ & 0.073 \\
Medium - $\mathrm{Fe} \mathrm{SO}_{4}$ & 1.98 & $8.7^{\mathrm{b}}$ & 99 & 1.90 & $6.6^{\mathrm{b}}$ & 0.075 \\
Medium - $\mathrm{ZnSO}_{4}$ & 1.98 & $8.7^{\mathrm{b}}$ & 99 & 1.90 & $6.6^{\mathrm{b}}$ & 0.075 \\
(control) & 1.99 & $8.8^{\mathrm{a}}$ & 100 & 1.93 & $6.7^{\mathrm{a}}$ & 0.077 \\
\hline LSD & \multicolumn{7}{c}{0.01} & & 0.07 & \\
\hline
\end{tabular}

- Standard inoculum was 0.22 gm dried cells /L.

- Values in column having the same letter are not significantly differed.

- Data were analyzed by Duncan's multiple range tests (1951). 
treatment (which contains all tested inorganic salts). The percentage of cell dry weight decrease (in medium lacking any tested salt) ranged between $91-99 \%$ for the tested strain. The tabulated data also revealed that the cell dry weight was affected by the absence of each salt. From the aforementioned results, it could be noticed that, the least cell dry weight and endotoxin concentration, was observed when $\mathrm{CaCO}_{3}$ or $\mathrm{KH}_{2} \mathrm{PO}_{4}$ were omitted from the medium. The corresponding dry weight was 8 and $8.2 \mathrm{gm} / \mathrm{L}$, respectively.

From the previous data of media lacking salts, it is obvious that the most effective inorganic salts in the medium, for mass production, were $\mathrm{CaCO}_{3}$, followed by $\mathrm{KH}_{2} \mathrm{PO}_{4}, \mathrm{MgSO}_{4}$ then $\mathrm{FeSO}_{4}$, which confirm the role of these ions on the growth, as well as confirm their buffering capacity. While the most effective inorganic salts for endotoxin production were $\mathrm{KH}_{2} \mathrm{PO}_{4}$ followed by $\mathrm{CaCO}_{3}, \mathrm{FeSO}_{4}$, $\mathrm{MgSO}_{4}$ then $\mathrm{ZnSO}_{4}$. The absence of $\mathrm{Ca}^{++}, \mathrm{K}^{+}$, $\mathrm{Fe}^{++}, \mathrm{Zn}^{++}$and $\mathrm{Mg}^{++}$resulted in decreasing the cell dry weight, by $9 \%, 7 \%, 1 \%, 1 \%$ and $2 \%$, respectively, the highest cell dry weight was obtained in the control treatment. There were significant differences in cell dry weight and endotoxin concentration between the control and all other treatments.

The importance of inorganic salts, in recombinant E. coli growth media, was studied by Ming and Kaspar, (1998). They reported that, the addition of $\mathrm{NaCl}(1 \%)$ to the medium, enhances acid tolerance.

Lee et al (2005) conducted experiments to compare between $E$. coli MG1655 grown under controled conditions and cells grown with a toxic, sublethal $\mathrm{ZnSO}_{4}$ concentration. Cultures were grown in a defined medium permitting maximum $\mathrm{Zn}$ bioavailability. They found that, zinc is an essential trace metal ion for growth, but an excess of $\mathrm{Zn}$ is toxic to microorganisms.

\section{Effect of environmental conditions}

In the following experiments, MR2 medium was used for studying the effect of environmental factors, namely $\mathrm{pH}$, incubation temperature and aeration on cell dry weight and endotoxin production by recombinant $E$. coli strain. Experiments were done on rotary shakers using shake flasks.

\section{a- Initial pH}

Five levels of $\mathrm{pH}$, ranging between 5.5 and 9.5 were chosen for this study. Changes in the density of the cultures, also endotoxin concentrations were monitored during growth, using modified MR2 medium at different $\mathrm{pH}$ values. It is well known that the $\mathrm{pH}$ of the growth medium is of great importance for cell density.

The medium was inoculated with standard inoculum suspension and incubated at $37^{\circ} \mathrm{C}$ for 36 $\mathrm{hr}$, and at the end of the experiment the cell dry weight and endotoxin concentration were determined. Data presented in Table (8) reveal that there were significant differences in cell dry weight and endotoxin concentration with all tested $\mathrm{pH}$ values. The proper $\mathrm{pH}$ value which gave high cell density for the tested strain was 7.0(the control), while the highest concentration of endotoxin was obtained when initial $\mathrm{pH}$ was adjusted at 7.5. These results indicate that, the $\mathrm{pH} 7.5$ was the most favorable one for endotoxin production $(6.8$ $\mathrm{mg} / \mathrm{L}$ ) by recombinant $E$. coli. The corresponding figure for content $(\%)$ was $0.078 \%$. All other tested $\mathrm{pH}$ values, either lower or higher than 7.5 , decreased endotoxin production. The effect of $\mathrm{pH}$ on the growth of recombinant $E$. coli was studied by Hyun et al (2001). They tested the amount and activity of glycosyltransferase, produced by recombinant $E$. coli, as affected by different $\mathrm{pH}$ values. They found that, the activity was increased by lowering the culture $\mathrm{pH}$ to 5.8 as compared to the enzyme produced at $\mathrm{pH}$ 7.0.

\section{b- Incubation temperature}

Temperature is one of the most important environmental factors influencing the growth and survival of bacteria. In the following experiment, MR2 medium with optimum $\mathrm{pH}$ value was used for studying effect of incubation temperature.

In this respect, six degrees of incubation temperature in addition to the control treatment were used, to study the temperature effect on cell density and endotoxin production by recombinant $E$. coli strain using shake flasks as batch culture. Data presented in Table (9) clearly show that the increasing of incubation temperature, from $20^{\circ} \mathrm{C}$ to $37^{\circ} \mathrm{C}$, increased cell dry weight, where the highest dry weight value being $(8.8 \mathrm{gm} / \mathrm{L})$ was noticed at $37^{\circ} \mathrm{C}$ incubation temperature. While the maximum concentration of endotoxin was obtained at $30{ }^{\circ} \mathrm{C}$ or $33{ }^{\circ} \mathrm{C}$ representing a diverse in the best degree of temperature for cell biomass or endotoxin production. The same conclusion was noticed by Hyun et al (2001) who stated that, the recombinant enzyme produced by recombinant E. coli increased by lowering the culture temperature from $37^{\circ} \mathrm{C}$ to $30^{\circ} \mathrm{C}$. Also, Huang et al (2002) found that recombinant bacterial pencillin acylase 
Table 8. Effect of initial pH on cell dry weight and $\delta$-endotoxin production of recombinant E.coli on MR2 medium, after $36 \mathrm{~h}$ at $37^{\circ} \mathrm{C}$ using shake flasks

\begin{tabular}{|cccccccccc|}
\hline & & \multicolumn{7}{c|}{ Initial pH } \\
\cline { 3 - 9 } & & 5.5 & 6.5 & 7.5 & 8.5 & 9.5 & 7.0 & Control & LSD \\
\hline & $\mathrm{gm} / \mathrm{L}$ & $7.9^{\mathrm{e}}$ & $8.3^{\mathrm{c}}$ & $8.7^{\mathrm{b}}$ & $8.0^{\mathrm{d}}$ & $7.5^{\mathrm{f}}$ & $8.8^{\mathrm{a}}$ & 0.07 \\
Cell dry weight & $\%$ & 86 & 94 & 99 & 91 & 81 & 100 & \\
\hline \multirow{2}{*}{ Delta-endotoxin } & $\mathrm{mg} / \mathrm{L}$ & $6.0^{\mathrm{d}}$ & $6.1^{\mathrm{c}}$ & $6.8^{\mathrm{a}}$ & $6.0^{\mathrm{d}}$ & $5.6^{\mathrm{e}}$ & $6.7^{\mathrm{b}}$ & 0.04 \\
& Content $(\%)$ & 0.075 & 0.073 & 0.078 & 0.075 & 0.074 & 0.077 & \\
\hline
\end{tabular}

- Values in columns having the same letter are not significantly differed.

- Standard inoculum was $0.22 \mathrm{gm} / \mathrm{L}$.

- Data were analyzed by Duncan's multiple range tests (1951).

Table 9. Effect of incubation temperature on cell dry weight and $\delta$ endotoxin production of recombinant $E$. coli on MR2 medium, after $36 \mathrm{~h}$ using shake flasks.

\begin{tabular}{|ccccc|}
\hline \multirow{2}{*}{$\begin{array}{c}\text { Temperature } \\
\left({ }^{\circ} \mathrm{C}\right)\end{array}$} & \multicolumn{2}{c|}{ Cell dry weight } & \multicolumn{2}{c|}{$\delta$-endotoxin concentration } \\
\cline { 2 - 5 } & $\mathrm{gm} / \mathrm{L}$ & $\%$ & $\mathrm{mg} / \mathrm{L}$ & Content $(\%)$ \\
\hline 20 & $6.0^{\mathrm{g}}$ & 68 & $3.0^{\mathrm{f}}$ & 0.050 \\
25 & $7.0^{\mathrm{f}}$ & 79 & $3.5^{\mathrm{e}}$ & 0.050 \\
28 & $7.5^{\mathrm{e}}$ & 81 & $4.3^{\mathrm{d}}$ & 0.057 \\
30 & $8.0^{\mathrm{c}}$ & 91 & $6.8^{\mathrm{a}}$ & 0.078 \\
33 & $8.1^{\mathrm{b}}$ & 92 & $6.8^{\mathrm{a}}$ & 0.080 \\
37 (control) & $8.8^{\mathrm{a}}$ & 100 & $6.5^{\mathrm{b}}$ & 0.076 \\
40 & $7.9^{\mathrm{d}}$ & 90 & $5.8^{\mathrm{c}}$ & 0.075 \\
\hline LSD & 1.3 & & 0.08 & \\
\hline
\end{tabular}

- Values in columns having the same letter are not significantly differed.

- Standard inoculum was $0.22 \mathrm{gm} / \mathrm{L}$.

- Data were analyzed by Duncan's multiple range tests (1951).

is usually expressed at low temperatures (less than $30^{\circ} \mathrm{C}$ ), in E. coli. Outside this range, cell physiology was seriously affected.

\section{C- Aeration}

\section{1- Effect of agitation speed}

Results of recombinant E. coli and endotoxin production as influenced by different agitation speeds were presented in Table (10). This table indicates that, increasing the agitation speed resulted in increasing the cell dry weight and endotoxin concentration till reaching the maximum (8.8 gm/L \& $6.8 \mathrm{mg} / \mathrm{L}$, respectively) during $32 \mathrm{hrs}$ of incubation; at $200 \mathrm{rpm}$. While, at lower or at higher agitation speed the production was drastically affected especially at higher speeds. At 200 rpm, recombinant $E$. coli grew during the incubation period and recorded the highest cell dry weight and endotoxin concentration.

\section{2-Effect of medium volume}

Results of recombinant E. coli and endotoxin production as affected by different medium volumes were presented in Table (11). Results revealed that, increasing the medium volume, in shake flasks, from 25 to $100 \mathrm{ml} / 250 \mathrm{ml}$ flask, resulted in increasing both cell dry weight and 
endotoxin concentration, till reaching the maximum being $8.8 \mathrm{gm} / \mathrm{L} \& 6.8 \mathrm{mg} / \mathrm{L}$, respectively when using $100 \mathrm{ml}$ medium/flask. While using medium volume over $100 \mathrm{ml} /$ flask resulted in disturbance of motion and in culture contamination. Therefore, it could be recommended to use $100 \mathrm{ml}$ of medium per $250 \mathrm{ml}$ flask for both biomass \& endotoxin production. Coleman et al (2003) studied the influence of agitation, inoculum density, $\mathrm{pH}$ and strain on the growth parameters of E. coli, using brain heart infusion broth medium. Significant effects of agitation and initial population density were identified at $10^{\circ} \mathrm{C}$ but not at 19 or $37{ }^{\circ} \mathrm{C}$. Strain viability was more apparent at the boundary conditions of growth of low $\mathrm{pH}$ and low temperatures.

On the light of the foregoing results, dealing with the effect of some factors on the cell biomass and $\delta$ - endotoxin production, by recombinant $E$. coli, it could be stated that the highest cell dry weight $(8.8 \mathrm{gm} / \mathrm{L})$, and the highest endotoxin concentration $(6.8 \mathrm{mg} / \mathrm{L})$, could be obtained by providing the following conditions in the medium: 1 - Sucrose $20 \mathrm{~g} / \mathrm{L}$ as carbon source.

2- Yeast extract $4 \mathrm{~g} / \mathrm{L}$ as a nitrogen source and growth promoter.

3- $\mathrm{CaCO}_{3}, \mathrm{~K}_{2} \mathrm{HPO}_{4}, \mathrm{MgSO}_{4}, \mathrm{FeSO}_{4}$ and $\mathrm{ZnSO}_{4}$ as mineral salts.

4- Initial $\mathrm{pH}$ at 7.0 for cell growth and at 7.5 for endotoxin production.

5- Incubation temperature at $37^{\circ} \mathrm{C}$ for cell growth and at $30^{\circ} \mathrm{C}$ for endotoxin production.

6- Hundred $\mathrm{ml}$ of medium / $250 \mathrm{ml}$ flasks at 200 rpm agitation speed.

\section{REFERENCES}

Abbott, W.S. (1925). A method of computing the effectiveness of an insecticide. J. Econ. Entomol. 18: 265 - 267.

Abdallah, N.A. (1990). The effect of small fragment substitution in the hypervariable region of the gene coding for $\delta$-endotoxin of Bacillus thuringiensis. Bulletin of Faculty of Agric. Cairo Univ., 41(2): 379-389.

Ahn, W.S.; S.J. Park and S.Y. Lee (2000). Production of poly 3- hydroxybutyrate by fed-batch culture of recombinant $E$. coli with a highly concentrated whey solution. Appl. Environ. Micrbiol. 66(8): 3624-3627.

Atlas, R.M. (1998). Handbook of Microbial Media. $2^{\text {nd }}$ Ed. p. 527, Edited by Parks, L. C. CRC Press, London.

Baum, J.A.; D.M. Coyle; M.P. Gilbert; C.S. Jany and B.C. Gawron (1990). Novel cloning vectors for Bacillus thuringiensis. Appl. Environ. Microbiol. 56(11): 3420-3428.

Chak, K.F. and D.J. Ellar (1987). Cloning and expression in Escherichia coli an insecticidal crystal protein gene from Bacillus thuringiensisvar. Aizawai HD-133. J. Gen. Microbiol. 133: 29212931.

Coleman, M.E.; M.L. Tamplin; J.G. Phillips and P.S. Marmer (2003). Influence of agitation, inoculum density, $\mathrm{pH}$ and strain on the growth parameters of $E$. coli $\mathrm{O} 157: \mathrm{H} 7$. International J. Food Microbiol., 83(2): 147-160.

Duncan, D.B. (1951). A significant test for differences between ranked treatments in an analysis of variance. Va. J. Sci. 2: 171-189.

Gamal, Rawia, F.; H.K. Bekhiet; Abeer, M. Mohammed and M. El-Sawy (2003). The effectiveness of formulation types of Egyptian Bacillus thuringiensis isolates against the $2^{\text {nd }}$ instar of Spodoptera littoralis. Arab Univ. J. Agric. Sci., Ain Shams Univ., Cairo, 11(2): 485-499.

Huang, S.W.; Y.H. Lin; H.L. Chin; W.C. Wang; B.Y. Kuo and C.P. Chou ( 2002). Effect of $\mathrm{pH}$ on high-temperature production of bacterial penicillin $G$ acylase in E. coli. Biotechnology Progress, 18(3): 668-671.

Hyun, J.H.; H.N. Soo; K.D. Hyuk and P.Y. Cheol (2001). Effects of environmental factors on expression of glycosyltransferase in recombinant E. coli. J. Microbiol. \& Biotechnol., 11(1): 9296.

Lee, S.Y. and J.I. Chol (1998). Polyhydroxyalkanoates biodegradable polymer. In: Manual of Industerial Microbiology and Biotechnology (2 $2^{\text {nd }}$ Ed.) pp. 616-627. Demain, A.L. and J.E. Davies (eds). ASM Press, Washington, D.C.

Lee, L.; J.A. Barrett and K.R. Poole (2005). Genome wide transcriptional response of chemostat cultured E. coli to zinc. J. Bacteriol., 187(3): 1124-1134.

Ling, H.; D. Magnus; E.S. Olof and H. Lena (2001). Effect of glycine on the cell yield and growth rate of E. coli: Evidence for cell-densitydependent glycine degradation as determined by 13C NMR spectroscopy. J. Biotechnololgy, 92(3): 237-249.

Litchfield, J.T. and F. Willcoxon (1949). A simplified method of evaluating dose effect experiments. J. Pharmacol. Exp. Therap. 96: 99 - 133. Liu, F.; W. Li; D. Ridgway and T. Gu (1998). Production of poly- $\beta$-hydroxybutyrate on molasses by recombinant $E$. coli. Biotechnology Letters, 20(4): 345-348. 
Liu, Y.C.; L.C. Liao and W.T. Wu (2000). Cultivation of recombinant $E$. coli to achieve high cell density with a high level of penicillin $G$ acylase activity. Proc. Natl. Sci. Counc. 24(4): 156-160. Marounek, M.; E. Skrivanova and V. Rada (2003). Susceptibility of E. coli to $\mathrm{C} 2-\mathrm{C} 18$ fatty acids. Folia Microbiologica, 48(6): 731735.

Ming, C.C. and C.W. Kaspar (1998). Growth and processing conditions affecting acid tolerance in E. coli O 157. H7. Food MicrobiologyLondon. 15(2): 157-166.

Mohammed, Abeer, M. (2003). Microbiological Studies on Bacillus thuringiensis Production. pp. 89-91. M.Sc. thesis, Fac. of Agric., Ain Shams Univ., Cairo.

Nikel, P.I.; M.J. Pettinari; B.S. Mendez and M.A. Galvano (2005). Statistical optimization of a culture medium for biomass and poly $\beta$ - hydroxybutyrate production by a recombinant $E$. coli strain using agroindusterial byproducts. International Microbiology 8: 243-250.

Painter, P.R. and A.G. Marr (1963). Mathematics of microbial populations. Annual Rev. Microbiol. 22: 229-234.

Shuishan, S.; H. Silke and S. Alexander (1999). Production of poly $\beta$ hydroxybutyric acid by fedbatch culture of recombinant strain of $E$. coli. Biotechnology Letters, 21(3): 193-197.

Sneath, P.H.A.; N.S. Mair; E.M. Sharpe and J.G. Holt (1986). Bergey's Manual of Systematic Bacteriology. ${ }^{\text {st }}$ Ed., Vol. 2, Edited by Williams \& Wilkins Press, Baltimore, U.S.A.

Trushin, M.V. (2003). Studies on distant regulation of bacterial growth and light emission. Microbiology, 149: 363-368.

Wang, F. and S.Y. Lee (1997). Production of poly $\beta$-hydroxybutyrate by fed-batch culture of filamentation-suppressed recombinant $E$. coli. Appl. Environ. Microbiol. 63(12): 4765-4769. 